\title{
PENGARUH JENIS PAKAN YANG BERBEDA TERHADAP PERTUMBUHAN DAN KELANGSUNGAN HIDUP IKAN MANFISH (Pterophyllum scalare)
}

\section{EFFECT OF DIFFERENT TYPES OF FEED ON THE GROWTH AND SURVIVAL OF MANFISH (Pterophyllum scalare)}

Ratih Pangestu Rahayu ${ }^{1 *}$ Ayu Adhita Damayanti ${ }^{1)}$ Bagus Dwi Hari Setyono ${ }^{1)}$
${ }^{1)}$ Program Studi Budidaya Perairan, Fakultas Pertanian, Universitas Mataram

\begin{abstract}
Abstrak
Penelitian ini bertujuan untuk mengetahui jenis pakan yang menunjang pertumbuhan dan kelangsungan hidup yang tinggi untuk ikan Manfish. Penelitian ini dilaksanakan selama 30 hari, yang bertempat di Instalasi Sendiri. Penelitian ini dilakukan dengan metode eksperimental dengan menggunakan Rancangan Acak Lengkap (RAL) dengan 4 perlakuan dan 3 kali ulangan. Perlakuan yang diberikan adalah pemberian pakan yang berbeda dan masing-masing perlakuan diulang 3 kali. Perlakuan yang diberikan yaitu : Perlakuan 0 (kontrol) : pemberian pakan menggunakan tubifex, Perlakuan 1 : pemberian pakan mengunakan jentik nyamuk, Perlakuan 2 : pemberian pakan mengunakan udang rebon, Perlakuan 3 : pemberian pakan kombinasi cacing darah dan udang rebon. Parameter yang di amati yaitu, panjang mutlak, berat mutlak, pertumbuhan spesifik, tingkat kelangsungan hidup dan kualitas air. Hasil menunjukkan setiap perlakuan tidak adanya pengaruh nyata perbedaan jenis pakan terhadap pertumbuhan dan kelangsungan hidup ikan manfish.
\end{abstract}

Kata kunci: ikan manfish, pertumbuhan, pakan, tingkat kelangsungan hidup

\begin{abstract}
This study aims to determine the type of feed that supports growth and high survival for Manfish. The research was carried out for 30 days, which took place in the Self Installation. This research was conducted by an experimental method using a Completely Randomized Design (CRD) with 4 treatments and 3 replications. The treatment given is different feeding and each treatment is repeated 3 times. The treatments given are: Treatment 0 (control): feeding using tubifex, Treatment 1: feeding using mosquito larvae, Treatment 2 : feeding using rebon shrimp, Treatment 3: feeding a combination of blood worms and rebon shrimp. The parameters observed were, absolute length, absolute weight, specific growth, survival rate and water quality. The results showed that there was no real effect of different types of feed on the growth and survival of manfish.
\end{abstract}

Keywords: manfish, growth, feed, survival rate.

\section{Pendahuluan}

Ikan hias air tawar memiliki potensi sebagai komoditas ekspor. Kementerian Keluatan dan Perikanan (KKP) menyatakan bahwa, saat ini Indonesia menduduki peringkat ketiga sebagai negara pengekspor

*Korespondensi:

Email: ratihpangesturahayu@gmail.com ikan hias di dunia setelah Singapura dan Malaysia. Suhendra (2010) dalam Wahyu (2012) menyebutkan nilai ekspor pada 2010 lebih dari 12 juta US Dollar dan menurut Erlangga (2012) dalam Wahyu 
(2012), nilainya meningkat hingga 16 juta US Dollar pada 2011. Nilai ekspor tersebut diprediksi menembus angka 19,2 juta US Dollar pada akhir 2012 (Wahyu, 2012).

Salah satu ikan hias air tawar yang banyak diminati adalah ikan manfish, ikan ini berasal dari perairan Amazon dan disebut juga dengan nama Angle Fish (ikan bidadari) karena bentuk dan warnanya yang menarik serta pergerakan yang tenang. Ikan hias yang akan diekspor dapat diperoleh dari benih yang berkualitas, baik jenis maupun ukurannya.

Permasalahan yang sering terjadi pada budidaya ikan hias khususnya benih manfish adalah rendahnya pertumbuhan (Putra et al., 2017). Salah satu penyebab rendahnya pertumbuhan ikan manfish ialah pakan yang diberikan kurang sesuai dengan kebutuhan nutrisi ikan. Nutrisi yang terdapat pada pakan Tubifex sp. yaitu protein $57 \%$, lemak 13,30\%, dan karbohidrat 2,04\% (Madinawati et al., 2011). Jentik nyamuk memiliki kandungan protein antara 48,72\% (Dahelmi, 2011 dalam To'buangan, 2016), dan udang rebon kandungan proteinnya mencapai $52,35 \%$ (Widinata et al., 2016). Oleh sebab itu penelitian tentang pengaruh jenis pakan yang berbeda terhadap pertumbuhan dan kelangsungan hidup ikan manfish (pterophyllum scalare) perlu dilakukan.

\section{Metode}

\section{Waktu dan tempat}

Penelitian ini dilaksanakan selama 30 hari mulai tanggal 8 Agustus - 6 September 2019 yang bertempat di Instalasi Pribadi Jalan Gili Air no 28B Mataram.

\section{Metode penelitian}

Penelitian ini dilakukan dengan metode eksperimental menggunakan Rancangan Acak Lengkap (RAL) dengan 4 perlakuan dan 3 kali ulangan. Perlakuan yang diberikan adalah:

Perlakuan 0 (kontrol) = Tubifex (P0)

Perlakuan $1=$ =Jentik nyamuk $(\mathrm{P} 1)$

Perlakuan $2=$ Udang rebon $(\mathrm{P} 2)$
Perlakuan 3

$=$ Kombinasi jentik nyamuk dan udang rebon (P3).

Parameter pengamatan

Parameter yang diuji adalah

Pertumbuhan panjang mutlak;

$$
\mathrm{PP}=\mathrm{Pt}-\mathrm{Po}
$$

Dimana, $\mathrm{PP}=$ Pertumbuhan panjang $(\mathrm{cm})$, $\mathrm{Pt}=$ Panjang individu ikan waktu ke-t $(\mathrm{cm})$, $\mathrm{Po}=$ Panjang individu ikan waktu ke-0 (cm).

Pertumbuhan Berat Mutlak;

$$
\mathrm{W}=\mathrm{Wt}-\mathrm{Wo}
$$

Dimana, $\mathrm{W}=$ Pertumbuhan berat mutlak ikan yang dipelihara (gr), Wt = Berat ikan pada akhir pemeliharaan (gr), Wo = Berat ikan pada awal pemeliharaan (gr).

\section{Laju Pertumbuhan Berat Spesifik;}

$$
L P H=\left[\frac{(L n W t-L n W o)}{t}\right] \times 100 \%
$$

Dimana, LPH= Laju pertumbuhan harian $(\%), \mathrm{Wt}=$ Bobot rata-rata benih di akhir pemeliharaan (gr), Wo $=$ Bobot rata-rata benih di awal pemeliharaan $(\mathrm{gr}), \mathrm{t}=$ Lama waktu pemeliharaan (hari).

\section{Laju Pertumbuhan Panjang Spesifik;}

$$
L P H=\left[\frac{(L n L t-L n L o)}{t}\right] \times 100 \%
$$

Dimana, LPH $=$ Laju pertumbuhan harian $(\%), \mathrm{Lt}=$ Panjang rata-rata benih di akhir pemeliharaan $(\mathrm{cm}), \mathrm{Lo}=$ Panjang rata-rata benih di awal pemeliharaan $(\mathrm{cm}), \mathrm{t}=$ Lama waktu pemeliharaan (hari).

\section{Rasio Konversi Pakan (FCR) ;}

$$
F C R=\frac{F}{(W t+d)-W o}
$$

Dimana, FCR = Food Conversion Ratio ( rasio konversi pakan), $\mathrm{Wt}=$ Berat ikan pada akhir penelitian (gr), Wo = Berat ikan pada awal penelitian (gr), $\mathrm{F}=$ Jumlah pakan yang dikonsumsi (gr).

Tingkat kelangsungan hidup;

$$
\mathrm{SR}=\frac{N t}{N o} \times 100 \%
$$

Dimana, SR = Kelangsungan hidup (\%), Nt = Jumlah ikan pada waktu ke-t (ekor), No = Jumlah ikan pada waktu ke-0 (ekor), dan pengamatan kualitas air, parameter yang diamati yaitu suhu menggunakan 
thermometer, DO menggunakan DO meter dan $\mathrm{pH}$ menggunakan $\mathrm{pH}$ meter. Data yang didapatakan dianalisis menggunakan Anova (Analisis Ragam) pada taraf nyata $5 \%$.

\section{Hasil}

Berdasarkan hasil penelitian mengenai pengaruh pemberian pakan yang berbeda terhadap pertumbuhan dan kelangsungan hidup ikan manfish maka didapatkan hasil pada parameter yang diamati, diantaranya: panjang total, panjang sirip, panjang tegakan, berat mutlak, pertumbuhan spesifik, tingkat kelangsungan hidup, dan kualitas air.

\section{Pertumbuhan Panjang Mutlak}

\section{a. Panjang total}

Berdasarkan hasil pengamatan pertumbuhan rata-rata panjang total pada pemeliharaan ikan manfish pada perlakuan P0 didapatkan hasil panjang total sebesar $0,22 \pm 0,03 \mathrm{~cm}$, perlakuan $\mathrm{P} 1$ didapatkan hasil panjang total sebesar $0,27 \pm 0,11 \mathrm{~cm}$, perlakuan P2 sebesar $0,09 \pm 0,03 \mathrm{~cm}$ dan perlakuan P3 sebesar $0,20 \pm 0,10 \mathrm{~cm}$. Berikut data hasil analisis yang disajikan pada (Gambar 4).

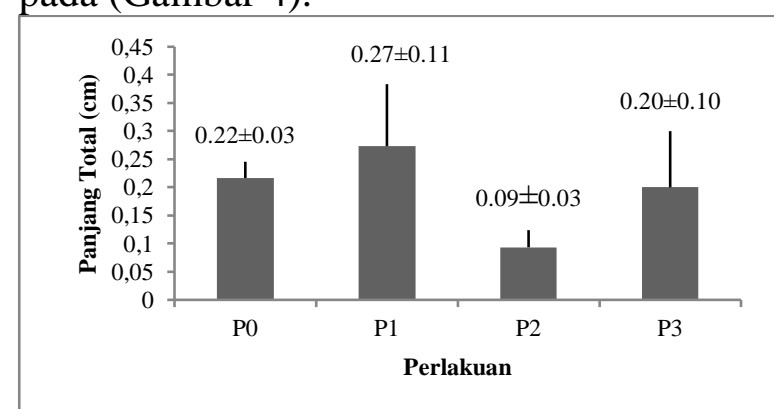

Gambar 4. Pertumbuhan Panjang Total Ikan Manfish. P0 (Tubifex), P1 (Jentik nyamuk), P2 (Udang rebon), P3 (Kombinasi Jentik nyamuk dan Udang rebon).

Hasil penelitian menunjukkan bahwa pemberian pakan yang berbeda memberikan pertumbuhan yang tidak signifikan, diduga karena seluruh pakan yang diberikan memiliki nutrisi yang sama untuk pertumbuhan ikan, sehingga semua alternatif pakan yang digunakan mampu meningkatkan pertumbuhan ikan manfish dalam tingkatan yang sama. Pernyataan tersebut sesuai dengan Sutarmat et al. (2010) dalam Hermawan et al. (2013) bahwa kandungan protein dalam pakan bisa mempengaruhi tinggi rendahnya pertumbuhan. Ikan pada stadia larva membutuhkan protein yang lebih tinggi dibandingkan ikan dewasa, dan tingkat protein optimum dalam pakan untuk pertumbuhan ikan berkisar 25-50\% (Maulidiyanti et al., 2015).

\section{b. Panjang sirip}

Ikan manfish merupakan ikan hias yang memiliki keunikan pada siripnya yang panjang, keunikan inilah yang menjadi daya tarik pembudidaya ikan hias untuk memelihara ikan manfish. Pertumbuhan panjang sirip ikan dapat dipengaruhi oleh beberapa faktor salah satunya adalah pakan. Pakan yang memiliki nutrisi tinggi dapat mempercepat pertumbuhan ikan sehingga semakin besar ikan, maka semakin panjang pula siripnya.

Pada penelitian ini didapatkan hasil pada perlakuan P0 pertumbuhan panjang sebesar $0,09 \pm 0,04 \mathrm{~cm}$, perlakuan P1 sebesar $0,14 \pm 0,02 \mathrm{~cm}$, pada perlakuan $\mathrm{P} 2$ sebesar $0,04 \pm 0,03 \mathrm{~cm}$, dan pada perlakuan P3 didapatkan pertumbuhan panjang sirip

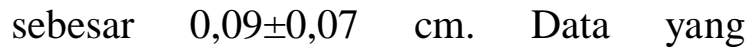
didapatkan dapat dilihat pada (Gambar 5).

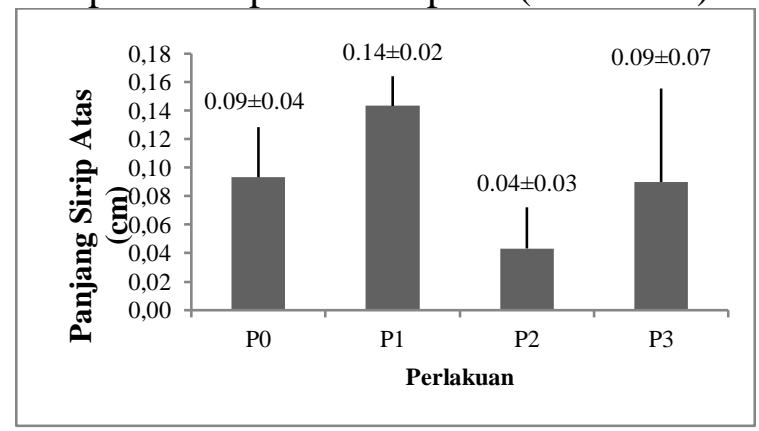

Gambar 5. Pertumbuhan Panjang Sirip Ikan Manfish. P0 (Tubifex), P1 (Jentik nyamuk), P2 (Udang rebon), P3 (Kombinasi Jentik nyamuk dan Udang rebon).

Berdasarkan hasil pengamatan yang dilakukan selama 30 hari pertumbuhan 
panjang sirip ikan manfish yang diberikan perlakuan pakan yang berbeda memberikan pengaruh yang tidak signifikan. Diduga karena ruang gerak serta oksigen yang disuplai sangat baik pada saat pemeliharaan. Terdapat pertambahan panjang sirip yang terjadi pada ikan yang dipelihara, meskipun penambahan panjang sirip antar perlakuan tidak berbeda nyata. Akan tetapi hasil yang diperoleh mengimplementasikan bahwa pakan yang digunakan dapat memberikan pertumbuhan panjang dari sirip ikan manfish yang dipelihara. Pernyataan Fujaya (2008) bahwa pada prinsipnya ikan memerlukan pakan untuk memenuhi kebutuhan energinya, baik energi diam, bergerak, beraktifitas, metabolisme maupun pertumbuhan. Sirip ikan akan semakin panjang seiring dengan bertambahnya umur dan ukuran ikan (panjang).

\section{c. Panjang tegakan}

Pertumbuhan tegakan ikan berbeda tergantung dari bentuk tubuhnya. Sutarmat et al. (2006) dalam Hermawan et al. (2013) menyatakan bahwa pertumbuhan ikan akan berbeda sesuai ukuran dan jenis ikan.

Pada penelitian ini didapatkan hasil pengukuran panjang tegakan, pada perlakuan $\mathrm{P} 0$ didapatkan panjang $0.05 \pm 0.05$ $\mathrm{cm}, \mathrm{P} 10,08 \pm 0,08 \mathrm{~cm}, \mathrm{P} 2 \quad 0,03 \pm 0,04 \mathrm{~cm}$, dan perlakuan P3 $0,06 \pm 0,07 \mathrm{~cm}$. Data yang didapatkan disajikan pada (Gambar 6).

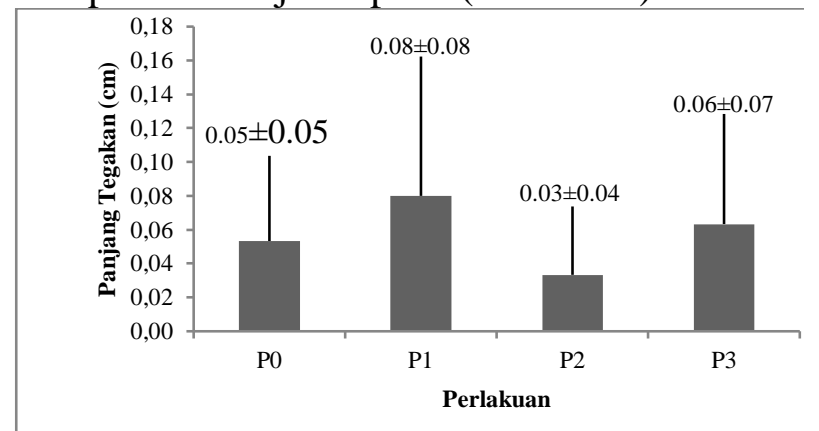

Gambar 6. Pertumbuhan Panjang Tegakan Ikan Manfish. P0 (Tubifex), P1 (Jentik nyamuk), P2 (Udang rebon), P3 (Kombinasi Jentik nyamuk dan Udang rebon).
Berdasarkan hasil pengamatan pertumbuhan panjang tegakan pada pemeliharaan ikan manfish bahwa pemberian pakan yang berbeda tidak berpengaruh nyata terhadap pertumbuhan panjang tegakan. Diduga karena pakan yang diberikan mampu memberikan pertumbuhan pada ikan manfish sehingga pertumbuhan tersebut mempengaruhi panjang tegakan. Ikan manfish memiliki bentuk tubuh yang lebar akan mempengaruhi panjang tegakannya dan apabila ikan merapatkan siripnya akan terlihat lebih teratur karena tegakannya yang panjang. Tegakan pada ikan manfish akan semakin panjang seiring dengan bertambahnya lebar tubuh ikan.

\section{Pertumbuhan Berat Mutlak}

Berdasarkan hasil analisis data menggunakan One-Way Annova diketahui bahwa pemberian pakan yang berbeda terhadap pertumbuhan berat mutlak memberikan hasil yang tidak signifikan. Pada perlakuan P0 didapatkan berat sebesar $0,52 \pm 0,03 \mathrm{~g}$, pada perlakuan P1 sebesar $0,53 \pm 0,04 \mathrm{~g}$, perlakuan P2 sebesar $0,51 \pm 0,02 \mathrm{~g}$, sedangkan pada perlakuan P3 didapatkan berat sebesar $0,50 \pm 0,05 \mathrm{~g}$. Hasil yang didapatkan disajikan pada (Gambar 7).

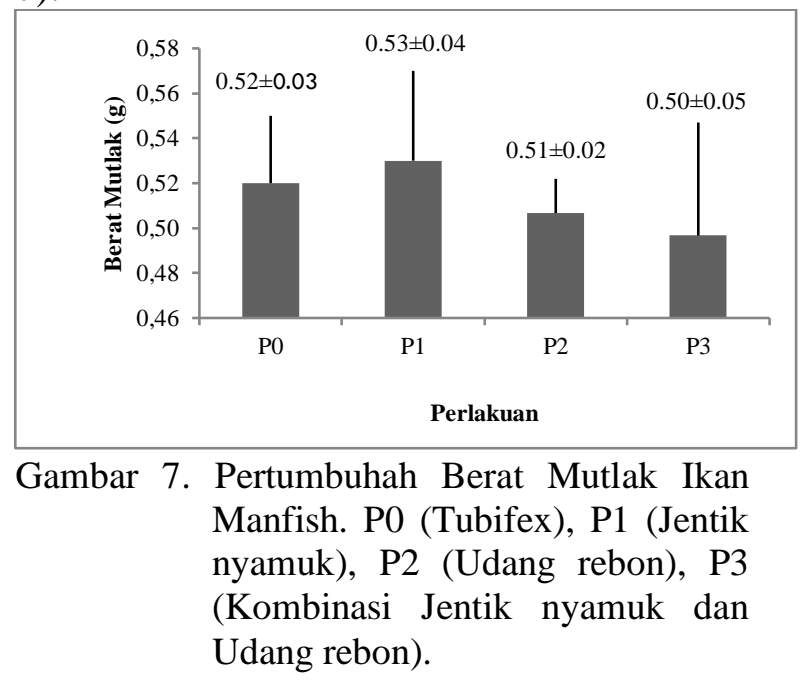

Pertumbuhan berat berkaitan dengan banyaknya jumlah pakan yang dikonsumsi sehingga menjadi daging pada ikan, data 
Jurnal Perikanan (2019) Volume 9. No. 2 : 137-144

DOI : https://doi.org/10.29303/jp.v9i2.157

berat ikan manfish yang diperoleh selama penelitian 30 hari menunjukkan, pemberian jenis pakan yang berbeda memberikan pengaruh yang tidak berbeda nyata pada setiap perlakuan. Hal ini diduga karena pakan yang diberikan berupa jentik nyamuk, udang rebon, dan kombinasi jentik nyamuk dan udang rebon mampu memenuhi kebutuhan nutrisi ikan manfish. Kandungan nutrisi yang baik akan mempercepat proses penambahan daging ikan sehingga dengan bertambahnya daging maka akan mempengaruhi pertambahan berat. Sutarmat et al. (2006) dalam Hermawan et al. (2013) ikan yang gemuk disebabkan asupan nutrisinya yang cukup dan lingkungan yang baik.

\section{Laju Pertumbuhan Panjang dan Berat Spesifik}

Data pertumbuhan panjang dan berat spesifik ikan manfish selama penelitian disajikan dalam bentuk gambar. Data pertumbuhan panjang dan berat spesifik ikan manfish dapat dilihat pada (Gambar 8 dan 9).

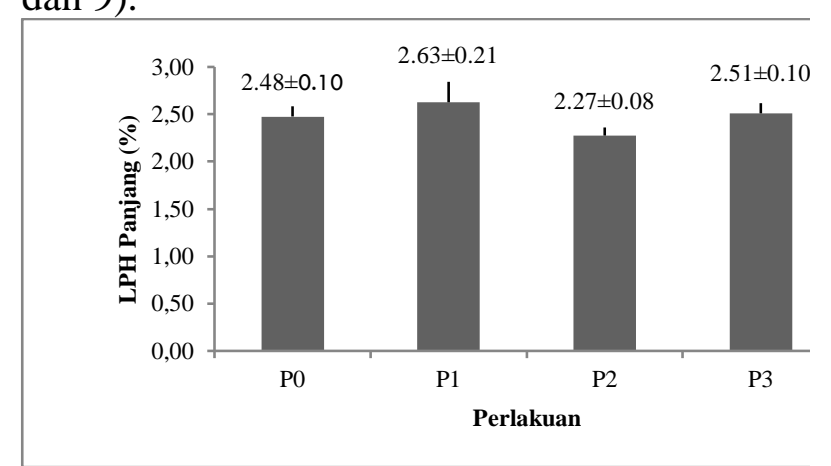

Gambar 8. Pertumbuhan Panjang Spesifik Ikan Manfish. P0 (Tubifex), P1 (Jentik nyamuk), P2 (Udang rebon), P3 (Kombinasi Jentik nyamuk dan Udang rebon).

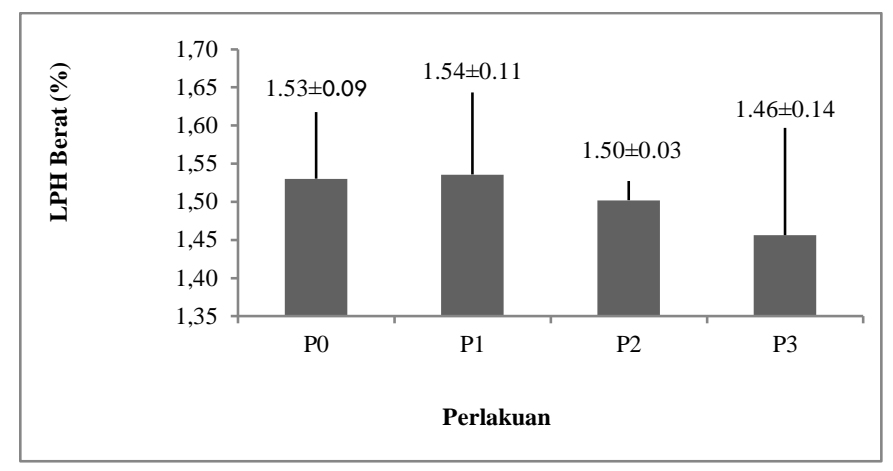

Gambar 9. Pertumbuhan Berat Spesifik Ikan Manfish. P0 (Tubifex), P1 (Jentik nyamuk), P2 (Udang rebon), P3 (Kombinasi Jentik nyamuk dan Udang rebon).

Laju pertumbuhan spesifik adalah persentase pertambahan berat dan panjang ikan setiap harinya selama pemeliharaan yang ditunjukkan dalam satuan persen (\%). Berdasarkan hasil penelitian selama 30 hari pemeliharaan, diperoleh data pertumbuhan panjang spesifik ikan manfish yaitu pada (Gambar 8). menunjukkan hasil P0 sebesar $2,48 \pm 0,10 \%, \quad \mathrm{P} 1 \quad 2,63 \pm 0,21 \%, \quad \mathrm{P} 2$ $2,27 \pm 0.08 \%$ dan P3 2,51 $\pm 0,10 \%$. Sedangkan data pertumbuhan berat spesifik ikan manfish di sajikan pada (Gambar 9). Data tersebut menunjukkan hasil P0 sebesar $1,53 \pm 0,09 \%$, P1 1,54 $\pm 0,11 \%$, P2 $1,50 \pm 0.03 \%$ dan P3 1,46 $\pm 0,14 \%$.

Setelah dilakukan analisis sidik ragam one-way Anova, bahwa perlakuan pemberian pakan yang berbeda memberikan hasil pertumbuhan panjang dan berat spesifik yang tidak berbeda nyata, diduga karena pakan yang digunakan memiliki nutrisi yang sama untuk pertumbuhan ikan manfish selain itu daya dukung lingkungannya yang baik mengakibatkan metabolisme ikan menjadi lancar, sehingga ikan dapat memanfaatkan pakan yang digunakan dengan baik pula untuk pertumbuhannya. Menurut Effendi (1997) dalam Sulasa et al. (2018) bahwa pertumbuhan ikan dipengaruhi oleh dua faktor yaitu faktor internal dan faktor eksternal. Faktor internal meliputi sifat genetik dan kondisi fisiologis ikan, 
sedangkan faktor eksternal berhubungan dengan pakan dan lingkungan.

\section{FCR (Rasio Konversi Pakan)}

Hasil analisis data menggunakan One-Way Annova (ANOVA) menunjukkan bahwa tidak ada pengaruh yang berbeda nyata terhadap setiap perlakuan. Hasil perhitungan FCR ikan manfish selama 30 hari pemeliharaan disajikan pada (Gambar $10)$.

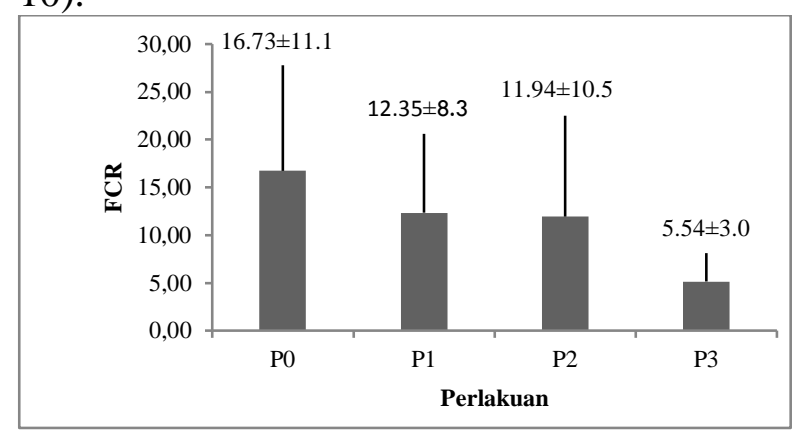

Gambar 10. Rasio Konversi Pakan (FCR). P0 (Tubifex), P1 (Jentik nyamuk), P2 (Udang rebon), P3 (Kombinasi Jentik nyamuk dan Udang rebon).

Berdasarkan Gambar 10, dapat dilihat bahwa nilai rasio konversi pakan berkisar antara 5,54 hingga 16,73. Perbedaan nilai FCR pakan tubifex, jentik nyamuk, udang rebon, dan kombinasi jentik nyamuk dengan udang rebon ditentukan dari kualitas pakan terhadap pertambahan bobot benih ikan manfish yang didapati pada akhir penelitian. Berdasarkan hasil penelitian P3 memberikan hasil FCR terendah hal ini menunjukkan semakin kecil nilai konversi pakan berarti tingkat efisiensi pemanfaatan pakan lebih baik, sebaliknya apabila konversi pakan besar, maka tingkat efisiensi pemanfaatan pakan kurang baik. Dengan demikian konversi pakan menggambarkan tingkat efisiensi pemanfaatan pakan yang dicapai. Iskandar et al. (2015) menyatakan bahwa konversi pakan merupakan perbandingan antara jumlah pakan yang diberikan dengan jumlah bobot ikan yang dihasilkan.

\section{Tingkat Kelangsungan Hidup (SR)}

Berdasarkan hasil analisis data menggunakan One-Way Annova diketahui bahwa pemberian pakan yang berbeda terhadap tingkat kelangsungan hidup memberikan hasil yang tidak signifikan. Data yang didapatkan dapat dilihat pada (Gambar 11).

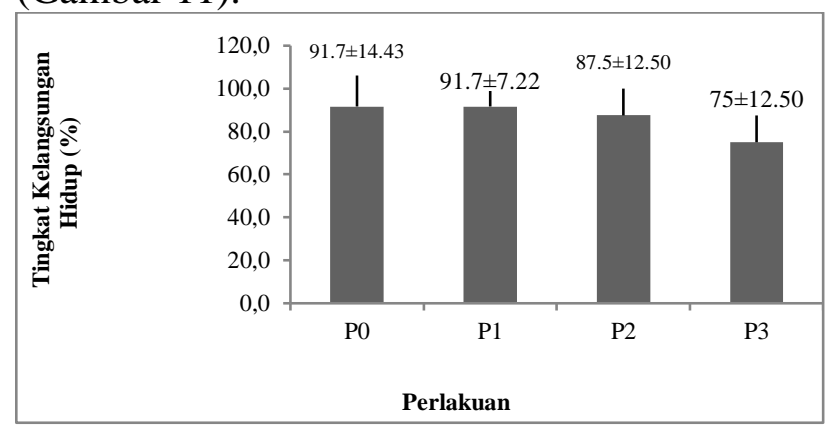

Gambar 11. Tingkat Kelangsungan Hidup Ikan Manfish. P0 (Tubifex), P1 (Jentik nyamuk), P2 (Udang rebon), P3 (Kombinasi Jentik nyamuk dan Udang rebon).

Pemberian pakan yang berbeda terhadap kelangsungan hidup ikan manfish tidak menunjukkan hasil yang berbeda nyata antar perlakuan P0, P1, P2 dan P3. Hal ini disebabkan karena pakan yang digunakan merupakan pakan yang biasa digunakan untuk pemeliharaan ikan manfish dan sesuai dengan bukaan mulut ikan. Hal ini sesuai dengan Mulyani et al. (2014) dalam Silaban (2018) menyatakan bahwa kelangsungan hidup ikan sangat bergantung pada daya adaptasi ikan terhadap makanan dan lingkungan, status kesehatan ikan, padat tebar, dan kualitas air yang cukup mendukung pertumbuhan ikan.

Pada (Gambar 11.) menunjukkan tingkat kelangsungan hidup ikan menurun. Hal ini diduga karena terjadi stres pada ikan saat dilakukan pengukuran awal, selain itu penurunan angka tingkat kelangsungan hidup pada P3 diduga karena pakan yang diberikan berupa kombinasi jentik nyamuk dan udang rebon memberikan pengaruh, yang dimana ikan lebih banyak memakan 1 jenis pakan yaitu jentik nyamuk sehingga udang rebon yang diberikan akan mengendap pada dasar 
perairan menyebabkan kualitas air keruh dan ikan stres kemudian mengalami kematian. Hal ini sesuai dengan pernyataan Gustrana (2008) dalam Andayani et al. (2018) bahwa tingkat kelangsungan hidup dari ikan yang dipelihara juga dipengaruhi oleh jenis pakan serta ketersediaan pakan yang digunakan pada saat pemeliharaan.

\section{Kualitas Air}

\begin{tabular}{lccl}
\hline No & Parameter & Kisaran & Literatur \\
\hline 1 & Suhu $\left({ }^{\circ} \mathrm{C}\right)$ & $25-27$ & $\begin{array}{l}25-29 \\
\text { (Yolanda, } \\
\end{array}$ \\
& & & $2016)$ \\
2 & DO (mg/l) & $5,11-$ & $4-6$ \\
& & 5,48 & (Adminrad \\
& & & 2008) \\
3 & pH & $6,5-6,9$ & $\begin{array}{l}6,5-7,0 \\
\text { (Susanto, } \\
\end{array}$ \\
& & & $2000)$ \\
\hline
\end{tabular}

Kualitas air memegang peran penting sebagai media tempat hidup ikan. Adapun parameter kualitas air yang diukur yaitu suhu, DO dan pH. Didapatkan hasil pengukuran suhu pada penelitian ini berkisar antara $25-27^{\circ} \mathrm{C}$. kisaran suhu tersebut merupakan kisaran suhu optimal untuk kehidupan ikan manfish. Pernyataan tersebut sesuai dengan Susanto (2000) bahwa ikan manfish yang dipelihara dalam akuarium hidup pada air bersuhu $20-26^{\circ} \mathrm{C}$, sedangkan menurut Yolanda (2016) suhu perairan yang berada pada kisaran $25-29^{\circ} \mathrm{C}$ masih berada dalam batas wajar dan tidak membahayakan kehidupan ikan manfish di daerah tropis.

Berdasarkan hasil pengukuran DO pada penelitian ini didapatkan hasil bahwa DO berkisar antara 5,11-5,48 mg/l. kisaran DO tersebut merupakan kisaran optimum untuk kehidupan ikan manfish. Oksigen terlarut yang diperlukan bagi ikan manfish bisa berkembangbiak dengan baik adalah 46 mg/l Adminrad (2008)

Pada penelitian ini didapatkan hasil $\mathrm{pH}$ dengan kisaran 6,5-6,9. Kisaran $\mathrm{pH}$ tersebut merupakan kisaran $\mathrm{pH}$ yang masih bagus untuk kehidupan ikan manfish. Pernyataan tersebut sesuai dengan Susanto (2000) bahwa kisaran pH yang mendukung pertumbuhan adalah 6,5-7,0.

\section{Kesimpulan}

Adapun kesimpulan dari penelitian ini ialah pakan yang berbeda memberikan hasil yang tidak signifikan terhadap pertumbuhan dan kelangsungan hidup ikan manfish sehingga semua jenis pakan yang digunakan baik tubifex, jentik nyamuk, udang rebon, dan kombinasi jentik nyamuk dengan udang rebon bisa menjadi alternatif lain untuk meningkatkan pertumbuhan dan kelangsungan hidup ikan manfish.

\section{Daftar Pustaka}

Adminrad. (2008). Budidaya Ikan Maanvis atau Angel Fish. Retrieved from http://bbatsukabumi.tripod.com/man fish.html.

Fujaya, Y. (2008). Fisiologi ikan. Jakarta: Rineka cipta.

Hermawan, D., Mustahal., Kuswanto. (2013). Optimasi Pemberian Pakan Berbeda Terhadap Pertumbuhan dan Kelangsungan Hidup Ikan Kerapu Macan (Epinephelus fuscoguttatus). Jurnal Perikanan dan Kelautan, Vol. 5 (1).

Iskandar, R. \& Elrifadah. (2015). Pertumbuhan dan Efisiensi Pakan Ikan Nila (Oreochromis niloticus) Yang Diberi Pakan Buatan Berbasis Kiambang. Jurnal ZIARAA'AH, Vol 40 (1): 1824 ISSN, 2355-3545.

Madinawati, N., Serdiati \& Yoel. (2011). Pemberian Pakan Yang Berbeda Terhadap Pertumbuhan Dan Kelangsungan Hidup Benih Ikan Lele Dumbo (Clarias gariepinus). Media Litbang Sulteng, Vol 4 (2), $83-87$.

Putra A. K., F. S. Mumpuni \& Rosmawati. (2017). Pengaruh Pemberian Pakan Alami Yang Berbeda Terhadap Pertumbuhan dan Kelangsungan 
Hidup Benih Ikan Maanvis (Pterophyllum scalare). Jurnal Mina Sains, Vol 3 (1).

Silaban, A. K. (2018). Pengaruh Pemberian Pakan Alami (Tubifex sp., Daphnia sp., Infusoria) Terhadap Pertumbuhan dan Kelangsungan Hidup Larva Ikan Nila (Oreochromis niloticus). [Skripsi]. Program studi manajemen sumberdaya perairan Fakultas pertanian Universitas Sumatera Utara.

Sulasa., Sri Hastuti dan Subandiyono. (2018). Pengaruh Enzim Papain dan Probiotik Pada Pakan dan Pertumbuhan Ikan Mas (Cyprinus carpio).Jurnal Sains Akuakultur Tropis, Vol 2 (1), 1-10.

Susanto, H. (2000). Maanvis. Jakarta: Penebar Swadaya.

To'buangan, A. (2016). Pengaruh Perbedaan Jenis Pakan Alami Jentik Nyamuk, Cacing Darah (Larva Chironomus sp.) dan Moina sp. terhadap Pertumbuhan Ikan Cupang (Betta splendens). Biota, Vol 1 (3).

Wahyu. (2012). Peningkatan Produksi Ikan Maanvis Pterophyllum scalare Dalam Budidaya System Resirkulasi Melalui Peningkatan Padat Tebar. [Skripsi]. Departemen budidaya Perairan Fakultas Perikanan dan Ilmu Kelautan Institut Pertanian Bogor.

Widinata, E., K. Muslih. \& A. Kurniawan. (2016). Pengaruh Pemberian Kombinasi Ekstrak Bunga Marigold (Tagetas erecta) dan Udang Rebon pada Pakan Terhadap Kecerahan Warna Ikan Koi (Cyprinus carpio carpio). Jurnal Sumberdaya Perairan, Vol 10 (2).

Yolanda, F. D., Sukendi \& H. Alawi. (2016). Gonad Maturation Of Angel Fish (Pterophyllum scalare) Induced By Laser Puncture Exposure At Diferent Time Duration. Student of Faculty of Fisheries and Marine Science Riau University. 